\title{
Security design, incentives, and Islamic Microfinance: Cross country evidence
}

\author{
Yaoyao Fan ${ }^{a^{*}}$, Kose John ${ }^{\mathrm{b}}$, Frank Hong Liu ${ }^{\mathrm{c}}$, Luqyan Tamanni ${ }^{\mathrm{d}}$ \\ ${ }^{a}$ International School of Business \& Finance, Sun Yat-sen University \\ ${ }^{b}$ Stern School of Business, New York University \\ ${ }^{c}$ Business School, University of Aberdeen \\ ${ }^{d}$ Business School, STEI Tazkia University
}

\begin{abstract}
We provide cross country evidence from microfinance institutions (MFIs) that are Sharia-compliant and their comparisons with non-Sharia-compliant MFIs. We find that, compared with non-Sharia-compliant conventional MFIs, Sharia-compliant Islamic MFIs have less credit risk but are less profitable and financially sustainable, have better poverty outreach, and are less likely to 'mission drift'. Our results highlight the differences in religiosity and security design between these two institutions. Our study also helps practitioners and investors improve the understanding of the difference between conventional and Islamic MFIs. The regulatory support for the development of Islamic MFIs is a feasible way to improve income of all poor Muslims.
\end{abstract}

Key words: microfinance institutions, Sharia-compliant product, Islamic, security design, religiosity, cross country.

JEL classification: G20, G21 


\section{Introduction}

Microfinance institutions (hereafter MFIs) have been recognised as an effective development tool and even as one of the main innovations in the past 25 years (Servin, Lensink, and Van den Berg, 2012; Hartarska, Shen, and Mersland, 2013). However, MFIs face some difficulties in penetrating regions with substantial Muslim populations, since conventional microfinance is not compatible with the financial principles in Sharia (Islamic law) (Karim, Tarazi, and Reille, 2008). A study conducted by the World Bank shows that over $30 \%$ of interviewed poor people from Jordan, Syria and Indonesia consider religious reasons the largest obstacle to microfinance. Consequently, a great demand for financing among the Muslim poor remains unmet.

Despite the high demand for and increasing popularity of Islamic microfinance institutions (Islamic MFIs) since the last decade, little is known about this type of financial institution. In this paper, we aim to investigate the financial and social performance of Islamic MFIs, in comparison with conventional MFIs. We conjecture that the Sharia compliance feature can help to mitigate the information asymmetry between lenders and borrowers for Islamic MFIs because of the role of religiosity and their special product design.

First, both lenders and borrowers of Islamic MFIs should not conduct any unethical behaviours to violate the guidance of Sharia law, whereas conventional MFIs have no such restriction. The religiosity could effectively reduce information asymmetry, as found in literature that religiosity promotes ethical attitudes (Terpstra, Rozell, and Robinson, 1973; Conroy and Emerson, 2004; Brammer, Williams, and Zinkin, 2007). Believers in God may be less willing to act unethically since they believe that an omniscient Goss will 'catch' them in the action or know their unethical thoughts or attitudes. The previous literature finds that firms in religious areas or countries are less likely to engage in financial reporting irregularities and to experience stock price crash, so they have reduced auditing prices, higher credit ratings and lower debt costs (McGuire, Omer, and Sharp, 2011; Callen and Fang, 2015; Kanagaretnam, Lobo, and Wang, 2015; Leventis, Dedoulis, and Abdelsalam, 2015; Jiang, John, Li, and Qian, 2016). Baele, Farooq and Ongena (2014) find that borrowers tend to default on their conventional rather than on their Islamic loans, and Islamic loans are less likely to default during Ramadan, a period of greater religious orientation.

Second, the product designs of the two institutions are different. Muslims are prohibited from taking or providing riba, which refers to interest or any predetermined return on a loan. 
The prohibition of riba is generally regarded as a part of Islam's general vision of a moral economy ${ }^{1}$. Hence, Islamic MFIs should comply with Sharia law, which prohibits the charging of interest, requires assets back up and promotes profit-and-loss sharing (PLS) schemes. This requirement leads to the main differences between the two types of financial institutions in the product designs, where Islamic MFIs tend to have equity-like products while conventional MFIs tend to have debt-like products. The equity-like and risk-sharing nature of Shariacompliant financial products could induce Islamic MFIs to have strong incentives to participate in and monitor the entrepreneurs' projects and may hence reduce the information asymmetry between lenders and borrowers and adverse selection cost. On the other hand, investment depositors of Islamic MFIs may also have more incentives to exercise tight oversight and discipline over the Islamic MFI management, since they need to share the risks (and normally do not have deposit insurance) (Čihák and Hesse, 2010). By risk-sharing, Islamic MFIs also reduce the debt risk-shifting effect documented in Karim (2001), Iqbal and Llewellyn (2002) and Obid and Naysary (2014).

Many Islamic MFIs use leasing contracts to get around the prohibition of making return on lending, which are also Sharia-compliant. By way of these leasing contracts, Islamic MFIs keep the ownership of the investment goods and rent them for a fee. As argued in Eisfeidt and Rampini (2009), in most legal environments, it would be easier for the lessor to regain control of the leased assets than it is for a lender who takes a security interest in an asset to repossess it. The higher ability to repossess the assets gives the Islamic MFIs an extra cushion for credit risk. While it is argued that although the separation of ownership and control in a leasing contract increases the agency costs from the borrower side (Eisfeidt and Rampini, 2009), it reduces the information asymmetry between the lender (Islamic MFIs) and the borrower from the lender's perspective.

Hence, if our conjecture that Islamic MFIs have lower information asymmetry between lenders and borrowers than conventional MFIs is true, we should predict that, compared with conventional MFIs, Islamic MFIs should be less profitable and financially self-sufficient, and have lower credit risk due to the costs associated with the Sharia-compliant products, have

\footnotetext{
${ }^{1}$ This principle could be traced back to the common medieval Arabic practice of doubling the debt if the loan has not been repaid when it is due. This practice in its extreme form had resulted in slavery medieval Arabia due to the lack of bankruptcy legislation that protects the borrower from failed ventures.
} 
better poverty outreach and are less likely to have 'mission drift', where financial sustainability is attained by sacrificing poverty outreach.

We employ data from the Microfinance Information Exchange Network, an international microfinance platform that provides data on individual MFIs. We construct a panel dataset that comprises 316 MFIs located in 12 countries within three regions, namely South Asia (SA), Middle East and North Africa (MENA), and Eastern Europe and Central Asia (EECA) during the period of 1998 to 2014. A large percentage of the poor in these three regions are practicing Muslims. We manually classify MFIs in the MIX Market as Islamic MFIs if these MFIs partly or fully provide Islamic microcredit products and services and classify the remaining MFIs as conventional MFIs. We find Islamic MFIs have lower credit risk, but lower profitability and lower self-sufficiency, higher poverty outreach, and are less likely to 'mission drift' than conventional MFIs. Our result holds when we employ propensity score matching (PSM) method.

Our paper extends the literature comparing Islamic and conventional bank/finance (Aggarwal and Yousef, 2000; Abedifar, Molyneux, and Tarazi, 2013; Gheeraert, 2014; Mallin, Farag, and Ow-Yong, 2014), and those on financial institutions and mutual funds (Abdelsalam, Fethi, and Matallin, 2014; Obid and Naysary, 2014; El-Ouadghiri and Peillex, 2018; Yanikkaya, Gumus, and Pabuccu, 2018; Alzahrani, 2019). Our paper highlights the important features of Islamic MFIs on both religiosity and product design, i.e., equity-like and leasing-like Shariacompliant products. We not only compare financial performance (profitability, financial selfsustainability and credit risk) between Islamic and conventional MFIs, but also study their differences in poverty outreach and the tendency of "mission drift", which are special features of MFIs.

Our research also extends and complements the current literature on microfinance. Extant literature has analysed microfinance's characteristics, such as capital structure, ownership and female leadership (Tchuigoua, 2015; Strøm, D’Espallier, and Mersland, 2014), cost efficiency (Caudill, Gropper, and Hartarska, 2009), financial performance (Mersland and Strøm, 2009; Hartarska, Shen, and Mersland, 2013; Islam, Nguyen, and Smyth, 2015), sustainability (Bogan, 2012) and technical efficiency (Derigs and Marzban, 2009; Servin, Lensink, and Van den Berg, 2012). As the only study examining the impact of religion on microfinance, the evidence of Mersland, D'Espallier, and Supphellen (2013) shows that compared with conventional MFIs, Christian MFIs have lower funding costs, lower 
profitability and similar credit risk. Our study sheds light on the impact of Islam, enshrined by a quarter of the world's population, on microfinance.

Our study is important and valuable to practitioners and investors related to MFIs. Our study helps them develop a comprehensive understanding of the difference between conventional and Islamic MFIs. This understanding could guide practitioners to take effective actions, such as generating strategies or other Sharia-compliant financial products to reduce operational costs. Therefore, in the real world, Islamic MFIs could increase their profitability and ability to sustain operations with no subsidies. Our study also has implications for policy makers in the Muslim world. Our evidence that Islamic MFIs have a better reach to the poor suggests that the regulatory support ${ }^{2}$ for the development of Islamic MFIs is a feasible way to improve income of all poor Muslims. For instance, in 1997, the Yemen government, along with the United Nations, initiates the Hodeidah Microfinance Program, which aims to apply the Islamic financial principles to the microfinance sector (Ahmed and Grace, 2001).

This paper is organised as follows. Section 2 overviews the Sharia-compliant products provided by MFIs. Section 3 reviews the relevant literature and develops our hypotheses. Section 4 discusses the data selection, measures and summary statistics. Section 5 displays the main results and their interpretations. Section 6 concludes.

\section{Sharia-compliant products in MFIs}

Most Islamic MFIs only offer two financial products: Murabaha and Qard-Hassan loans (El-Zoghbi and Tarazi, 2013). Under Murabaha financing, the financial institution buys an asset on behalf of the entrepreneur. The financial institution then resells this asset to the entrepreneur at a predetermined price that includes the original cost and an added profit margin. The entrepreneur makes payment to the financial institution in lump sum or in instalments in the future. The financial institution transfers the ownership to the entrepreneur when all payments are made. Murabaha financing is the classical and most widely offered instrument for trade financing. Qard-Hassan loans, translated as "beautiful loans" or "benevolent loan", is a type of loans in Islamic banking without any interest, although borrowers can pay back extra money as thanks.

\footnotetext{
${ }^{2}$ Regulatory support for Islamic MFIs in particular countries is shown in Appendix B.
} 
As a 'cost plus mark-up' sale contract, Murabaha is employed to finance goods and services needed as working capital. The mark-up is distinct from interest since it remains fixed, even if the repayment is overdue. Murabaha is the most popular and largest Islamic microfinance product, with the broadest outreach. Since Murabaha is tied to a particular asset, such as property, plant and equipment, it is less flexible than the commutable loan payment provided by conventional MFIs. Further, managing the transfer of assets of Islamic MFIs creates much higher operational costs than managing the cash distribution of conventional MFIs. Not tied to assets, Qard-Hassan loans are comparably easy to administer, so these loans have become the second largest Islamic microfinance product after Murabaha. But they are often not priced to cover their administrative costs (such charges are not permitted) and default costs.

As to another two Islamic financial products, Musharaka and Mudaraba, underlying profit-and-loss sharing (PLS) schemes, are mostly encouraged by Sharia but are rarely offered by Islamic MFIs. Musharaka and Mudaraba require Islamic MFIs to share profits or losses with both investors and entrepreneurs. Specifically, under Mudarabah financing, the financial institution provides capital and the entrepreneur contributes effort and exercise by entirely controlling the business. If the business suffers a loss, the financial institution obtains no or a negative return on its investment and the entrepreneur earns no compensation for his/her effort. If the business generates a gain, the profits are split based on a pre-negotiated equity percentage.

Under Musharaka financing, the financial institution and the entrepreneur jointly supply the capital and manage the business. Losses are absorbed based on the proportion of capital contribution, while profit proportions are negotiated freely. These two instruments are similar to equity investments: Mudarabah financing is closer to a limited partnership and Musharaka financing is closer to an equity stake with controlling rights. These two products specifically require prudent reporting and high-level transparency to ensure that profits and losses are distributed fairly. Consequently, these two products result in tremendous operational costs in scrutiny, particularly for micro and small enterprises that are not used to formal accounting.

\section{Hypotheses development}

Compared with conventional MFIs, Islamic MFIs comply with Sharia law, which prohibits the charging of interest and promotes profit-and-loss sharing (PLS) schemes and 
leasing-like product. Consequently, conventional MFIs and Islamic MFIs reveal different business models and mission orientations, which might influence their corresponding financial and social performance. However, the extant literature remains unclear about the differences in financial performance, credit risk and social performance between conventional and Islamic MFIs. We formulate our hypotheses in this section.

\subsection{Hypotheses on financial performance}

While the costs of capital for both conventional and Islamic MFIs are relatively low, the costs of capital for Islamic MFIs should be lower than those for conventional MFIs. First, although conventional MFIs receive subsides in the form of voluntary donations, these subsides, conditional on economic conditions, are quite unstable. Islamic charity, such as Zakat (obligatory alms tax), Sadaqah (voluntary donation) and Waqf (perpetual trust endowment), is an exclusive source of financing for Islamic MFIs. Zakat is considered as a reliable source of massive interest-free funds since Muslims compulsorily replenish it annually. El-Zoghbi and Tarazi (2013) reports that almost half of Islamic MFIs rely on Zakat to finance some parts of their operations. Second, conventional MFIs receive subsidized debts and equities, which are below the market rates, from aid agencies and financial markets respectively (Hermes and Lensink, 2011; Hudon and Traca, 2011). Banned to the charge of interest by Sharia, Islamic MFIs receive subsidized Qard-Hassan loans, which are interest-free, from financial markets. According to El-Zoghbi and Tarazi (2013), one third of Islamic MFIs sole rely on Qard-Hassan loans as the source of financing.

Islamic MFIs face less information asymmetry between lenders and borrowers than conventional MFIs, due to the role of religiosity and their product design. Firstly, both lenders and borrowers of Islamic MFIs prefer not to take unethical actions, which violate Sharia law, but those of conventional MFIs do not face this pressure. Most prior literature shows that religiosity could effectively prevent unethical actions, such as financial reporting irregularities, and then reduce information asymmetry, such as lower auditing prices, higher credit ratings and lower debt costs (McGuire, Omer, and Sharp, 2011; Callen and Fang, 2015; Kanagaretnam, Lobo, and Wang, 2015; Leventis, Dedoulis, and Abdelsalam, 2015; Jiang, John, Li, and Qian, 2016). According to Baele, Farooq and Ongena (2014), borrowers tend to default on their conventional rather than on their Islamic loans. Secondly, compared with the debt-like nature of conventional financial products, the equity-like and risk-sharing nature of Sharia-compliant 
financial products create stronger incentives for Islamic MFIs to participate in and monitor the entrepreneurs' projects, and for investment depositors of Islamic MFIs to exercise extensive oversight and discipline over the Islamic MFI management. As a result, the information asymmetry between lenders and borrowers is effectively reduced.

Since Islamic MFIs may have relatively lower cost of capital and lower information asymmetry, we hypothesise that:

\section{H1a: Islamic MFIs are more profitable and sustainable than conventional MFIs}

One the other hand, since most Islamic financial products are tied to tangible assets, the operational costs of Islamic MFIs are expected to be higher than conventional MFIs. Managing the transfer of assets involved in financial products creates much higher operational costs than managing the cash distribution used in conventional MFIs. Islamic MFIs' financial products under PLS schemes require prudent reporting and high-level transparency to ensure that profits and losses are distributed fairly, further increasing the operational costs in scrutiny. This requirement is particularly costly for micro and small firms that are not accustomed to formal accounting. Although not tied to assets, Qard-Hassan loans are often not priced to cover their administrative costs (such charges are permitted) and default costs.

In Islamic contracting, gharar (uncertainty and risk) is not allowed in order to prevent the weak from being exploited or one gaining at the expense of another. According to Abedifar, Molyneux, and Tarazi (2013) and Beck, Demirgüç-Kunt, and Merrouche (2013), the prices of Islamic financial products are much lower than conventional ones. Conventional MFIs usually charge their financial products nominal interest rates up to $60 \%$, and even higher interest rates when repayment is overdue as a penalty (Dehejia, Montgomery, and Morduch, 2012). However, for the two main Islamic MFI products, Murabaha only charges a fixed mark-up with no penalty for overdue repayment and Qard-Hassan loans do not charge any fees. Mark-up is based on the prevailing interest rates used by the non-Muslim world, such as London Interbank Offered Rates (LIBOR) or Base Lending Rate (BLR). Abedifar, Molyneux, and Tarazi (2013) document that Islamic finance does not extract rents (higher loan or lower deposit rates) for providing Islamic financial products. According to Beck, Demirgüç-Kunt, and Merrouche (2013), Islamic finance does not charge higher fees and commissions to compensate for the lack of interest revenue. 
Finally, Muslims are prohibited to invest in non-halal related businesses or conduct certain businesses, such as sale of pork, alcohol and tobacco, gambling and weapons. In addition, Shariah principle also requires that the commodity to be sold must exist, so derivatives, such as futures and options, are prohibited. These prohibited financial activities and products are known to be more profitable but riskier.

Since Islamic MFIs may have higher operational costs and lower price charges for their products and services, and have more restrictions on the business product ranges than conventional MFIs, we hypothesise that:

\section{H1b: Islamic MFIs are less profitable and sustainable than conventional MFIs}

\subsection{Hypotheses on risk}

The religious belief of Islamic MFI clients might induce loyalty and stem default (Abedifar, Molyneux, and Tarazi, 2013; Baele, Farooq, and Ongena, 2014), and thus reduces the credit risk of Islamic MFIs. For borrowers of Islamic MFIs, taking out Islamic loans means conducting economic activity encouraged by Sharia (i.e. 'putting your money where your mouth is'). It is unlikely that Muslims take out Islamic loans to conduct arbitrary activities, because Sharia prohibits the misappropriation of other people's property (i.e. 'eating other people's money in an unlawful way'). Thus, Muslim borrowers have a higher propensity to fulfil their obligations under Islamic loan contracts, leading to lower default risk. Additionally, the extant literature reveals a positive relation between religiosity and an individual's risk aversion (Hilary and Hui, 2009; Shu, Sulaeman,, and Yeung, 2012; Abedifar, Molyneux, and Tarazi, 2013; Adhikari and Agrawal, 2016; Jiang, John, Li, and Qian, 2016).

Equity-like and risk-sharing nature of Islamic financial products could also suppress the default risk. First, Islamic MFIs could effectively control the project risk during the ongoing process, since their role changes from project monitor to project participant. For instance, under the Mudaraba contract, while the entrepreneurs have the ultimate control over their businesses, major investment decisions, containing the participation of other investors, have to be approved by Islamic institutions (Beck, Demirgüç-Kunt, and Merrouche, 2013). Second, investment depositors of Islamic MFIs also have more incentives to exercise tight oversight and discipline 
over the Islamic MFI management, since they need to share in the risks (and normally do not have deposit insurance) (Čihák and Hesse, 2010). ${ }^{3}$

Various Sharia-compliant Islamic MFIs employ leasing contract to get around the forbidden of obtaining return on lending. Under these leasing contracts, Islamic MFIs maintain the ownership of the investment goods and lease it for a commission. According to Eisfeidt and Rampini (2009), in most legal environments, compared with a lender who takes an interest in an asset, a lesser is easier to regain control of the assets, because he/she has the ownership of the asset. This ability endows the Islamic MFIs an extra cushion for credit risk. Although the separation of ownership and control in a leasing contract raises the agency costs from the borrower side (Eisfeidt and Rampini, 2009), it lessens the lend-borrower information asymmetry.

Based on users' religious belief, religious attitude toward risk, and equity-like and risksharing nature of Islamic financial products, as well as leasing-like products, we hypothesise that:

\section{H2a: Islamic MFIs have lower credit risk than conventional MFIs}

On the other hand, Islamic MFIs might have a higher credit risk than conventional MFIs, due to the nature of their product designs. Compared with conventional loan contracts, Islamic loan contracts (Murabaha), the largest Islamic microfinance product, are more complex because they involve purchase and resale of products. This characteristic exposes Islamic MFIs to credit risk due to the fluctuation of commodity prices and the ownership transfer at the end of the repayment period. For instance, under a Murabaha contract, an Islamic MFI buys a house on behalf of a family at $\$ 50,000$ and the family needs to repay $\$ 500$ per month for ten years $(\$ 60,000$ in total; mark-up $=20 \%$ of the principal). At the beginning of the second year, the price of the house might drop to $\$ 40,000$. In this case, if the family defaults on this contract and initiates a new one, the total cost would be $\$ 54,000(\$ 500 * 12+\$ 40,000+\$ 40,000 * 0.2)$, lower than the cost of the original one.

\footnotetext{
${ }^{3}$ Idiosyncratic risk of Islamic MFIs, however, may be higher than conventional MFIs because equity-like nature of Islamic financial products may expose Islamic MFIs to the fluctuation of commodity prices, and the absent or fixed default penalty linked to Islamic MFIs' products may lead to increased losses given default. In addition, Sharia restrictions tend to increase asset concentration and prevent the use of hedging instruments for MFIs.
} 
Islamic MFIs usually do not charge a penalty for default, since a default penalty is not compliant with Sharia. In some cases, Islamic MFIs might use rebate to replace default penalty. The mark-up attached to the partnership loans (Murabaha) implicitly include both the return and a default penalty component of the Islamic MFIs. If the borrower repays the loan in a timely manner, then he/she will obtain the rebate. Thus, Islamic MFIs collect the delayed penalty over the whole financing period, while conventional MFIs calculate default interest payments over the delayed period (Abedifar, Molyneux, and Tarazi, 2013). The absent or fixed default penalty associated with Islamic MFIs is quite limited compared to the crescent default interest payments of conventional MFIs, resulting in increased credit risk for Islamic MFIs.

Base on the differences in the complexity of conventional and Islamic products and in default penalty of conventional and Islamic products, we hypothesise that:

\section{H2b: Islamic MFIs have higher credit risk than conventional MFIs}

\subsection{Hypotheses on outreach and mission drift}

Poverty outreach includes breadth and depth; this is seen specifically in Islamic MFIs as number of clients in a given period and the extent of penetration to the poorest at the beginning of the period, respectively. Scholars consider breadth of outreach as a measure of microfinance quantity, and depth of outreach as a measure of microfinance quality. Recently, a group of scholars has noticed a phenomenon called 'mission drift', in which financial sustainability is attained by sacrificing poverty outreach (Cull, Demirgüç-Kunt, and Morduch, 2007; Hermes, Lensink, and Meesters, 2011). In other words, MFIs may have shifted their orientation from social mission (outreach) fulfilment to profit generation. This is because the unit transaction costs in terms of screening, monitoring and administration costs linked to smaller loans are higher than those linked to larger loans. Nobel Peace Prize winner Muhammad Yunus has said that clients who are financially better off crowd out poorer clients in any credit scheme.

The distinction in the company culture and business model of conventional and Islamic MFIs might differentiate their performance in serving the poor and sticking to the mission. Embedded with both ethical and religious responsibility, Islamic MFIs have a stronger motivation than conventional MFIs to fulfil their social mission (outreach) and not to drift away. Conventional MFIs operate in an environment where maximising capital and wealth are as 
important as helping the poor, while Islamic MFIs operate in an environment where the equal distribution of social welfare is the priority and speculative behaviours are strictly forbidden (like 'mission drift'). Also, Islamic MFIs may have a stronger sense of duty and obligation to poor Muslims, who are excluded by banks and financial institutions but are unwilling to accept microfinance that is not compliant with Sharia (Karim, Tarazi, and Reille, 2008; Mohieldin, Iqbal, Rostom, and Fu, 2011).

Due to the different price-charge features of their financial products, Islamic MFIs might attract more poor customers, particularly the poorest customers, than conventional MFIs. According to Dehejia, Montgomery, and Morduch (2012), conventional MFIs often charge their financial products very high nominal interest rates of up to $60 \%$, and even higher interest rates for overdue repayment as a penalty. Critics of conventional MFIs posit that microfinance has driven the poor into a debt trap, in some cases even causing suicide (Sundaresan, 2008; Biswas, 2010). Such sky-high interest rates might frighten and inhibit the poor, particularly the poorest, who are less capable of repaying loans. In contrast, Islamic finance does not extract rents (higher loan rates) (Abedifar, Molyneux, and Tarazi, 2013) and does not charge higher fees and commissions to compensate for the lack of interest revenue (Beck, Demirgüç-Kunt, and Merrouche, 2013). As such, the poor feel comfortable obtaining loans from Islamic MFIs.

Compared with conventional MFIs which experience commercialisation or 'mission drift' to some extent (Navajas, Conning, and Gonzalez-Vega, 2003; McIntosh, Janvry, and Sadoulet, 2005; Cull, Demirgüç-Kunt, and Morduch, 2007), Islamic MFIs, which are still in their infancy, are less likely to do so. Firstly, Islamic MFIs face no or much less competition which might stimulate commercialisation, because the market need for Islamic financial products is far more than the market supply for Islamic financial products. Practicing Muslims make up a large proportion of the poor around the world, and an estimated 650 million Muslims live on less than $\$ 2$ a day (Obaidullah and Khan, 2008). Secondly, Islamic MFIs are not technically and operationally prepared for commercialisation. Financial principles enshrined in Sharia limit Islamic MFIs' capability to sustainably provide Sharia-compliant financial products at scale (El-Zoghbi and Tarazi, 2013). One principle is the prohibition on interest, which makes the application of a traditional microloan model technically impossible. Another principle is the encouragement of wealth generation through equity participation in business activities, which requires risk-sharing by financial service providers but does not guarantee returns. 
Based on the differences in attitudes towards economic and social missions, product features and development stages between conventional and Islamic MFIs, we hypothesise that:

\section{H3: Islamic MFIs have better poverty outreach than conventional MFIs}

H4: Islamic MFIs are less likely to experience mission drift than conventional MFIs

\section{Data, measures and descriptive statistics}

\subsection{Data collection and selection}

We collect MFI information from the MIX Market database, a worldwide microfinance information platform for MFIs. This database contains information voluntarily reported by individual MFIs about their financial statements and balance sheets. Since most of these financial statements and balance sheets are audited, this database is considered accurate and reliable. However, we should also note that this database does not contain information from all MFIs because many MFIs choose not to report to this data platform. We denominate all financial variables into US dollars and adjust for country-specific inflation. We identify 316 MFIs (including 281 conventional MFIs and 35 Islamic MFIs) operating in three regions, including South Asia, Middle East and North Africa, and Eastern Europe and Central Asia, over the period of 1998 to $2014.37 \%$ of the poor in these three regions are practicing Muslims. After adjusting for missing data, our final sample contains 1,909 firm-year observations.

We manually classify MFIs in the MIX Market database into two categories, conventional or Islamic, in light of the following procedures. We first identify regions with a presence of both conventional and Islamic MFIs and remove the remaining regions from the database. We then distinguish Islamic MFIs from conventional MFIs in these selected regions. Following Abedifar, Molyneux, and Tarazi (2013), we define Islamic MFIs as entities that offer Islamic microcredit products and services. Namely, Islamic MFIs are MFIs that fully or partially provide Sharia-compliant products or services. Some Islamic MFIs are well known, while others are easily identified through their unique names, for example, Muslim Aid (Bangladesh), Akhuwat (Pakistan) or BMT (Indonesia). There exists 33 MFIs that only provide Sharia-compliant products or services, and 2 MFIs with a separate business branch that particularly provide Sharia-compliant products or services in the database. Appendix D presents all Islamic MFIs and their locations. 


\subsection{Empirical methods and variables}

We examine the difference between conventional and Islamic MFIs, and our baseline regression model is presented below:

$Y_{i, t}=\alpha+\beta_{1} *$ Islamic MFI $_{i, t}+\beta_{2} *$ Controls $_{i, t}+\beta_{3} *$ Country $_{i}+\beta_{4} *$ Year $_{t}+\varepsilon_{i, t}(1)$

where $Y$ represents three groups of dependent variables, which are Financial Performance, Credit Risk and Outreach. The variable of primary interest, Islamic MFI, is a dummy variable that equals one if an MFI is Islamic, and 0 if it is conventional. Country and Year control for both country and year fixed effects.

Following prior studies, we construct four measures to represent an MFI's financial profitability: 1) Operational Costs; 2) Administrative Costs; 3) Return on Assets (ROA); and 4) Operational Self-Sufficiency (OSS). ${ }^{4}$ Although not-for-profit organisations employ a wide range of measures to represent their cost and profitability, similar to for-profit organisations, these four measures are the most widely employed. Market performance measures are not applicable since the MFIs in our database are not listed. Operational Costs are defined as the operational costs divided by the loan portfolio, and mainly contain wages and administrative costs. Administrative Costs are measured as the total administrative costs on the loan portfolio divided by the total assets. As the traditional for-profit-maximization measure across different institutions, $R O A$ is defined as the ratio of net operating income to total assets. Operational Self-Sufficiency (OSS) is defined as total financial revenue divided by the sum of financial expense, operating expense and loan loss provision expense. If an MFI's OSS is above $100 \%$, it indicates that this MFI is operationally self-sufficient. If an MFI's OSS is above $110 \%$, it indicates that this MFI is financially self-sufficient (Bogan, 2012). OSS mirror the MFIs' ability to sustain their operations without subsidies, while ROA mirrors the MFIs' ability to generate profits using their assets.

Following Gutiérrez-Nieto, Serrano-Cinca, and Molinero (2009), Mersland and Strøm (2009) and Bogan (2012), we employ three measures of credit risk: 1) Portfolio at Risk >90days (PaR>90days); 2) Write-off Ratio; 3) Loan Loss Rate. For lending institutions, the default possibility (Portfolio at Risk) is a crucial management measure since non-payments result in default losses (Write-off), which might impact their financial feasibility and future

\footnotetext{
${ }^{4}$ These four measures are employed in Mersland and Strøm (2009), Ahlin, Lin, and Maio (2011), Galema, Lensink, and Spierdijk (2011), Servin, Lensink, and Van den Berg (2012), Strøm, D’Espallier, and Mersland (2014), Tchuigoua (2015), and Randøy, Strøm, and Mersland (2015).
} 
survival. $P a R>90$ days is the percentage of the portfolio that is overdue for more than 90 days. Write-off Ratio is the percentage of the total amount of loans written off to gross loan portfolio. Loan Loss Rate is the ratio of the difference between write-offs and loans recovered to gross loan portfolio. A higher proportion of loan delay, write-off and loss implies higher credit risk.

Since information on the income or wealth of individual borrowers to measure their poverty levels is not available, prior studies tend to use the following two indicators as proxies of poverty outreach: 1) Number of Active Borrowers; 2) Average Loan Size to GNI/Capita (Cull, Demirgüç-Kunt, and Morduch, 2007; Mersland and Strøm, 2009; Louis, Seret, and Baesens, 2013; Roberts, 2013). Number of Active Borrowers reflects the total number of individuals that an MFI serves. More active borrowers indicate greater poverty outreach, because, holding the total lending constant, the number of borrowers that an MFI can reach is inversely related to the number of borrowers. Average Loan Size is the average loan size per borrower divided by country group national income per capita. Smaller loans are usually taken by poorer borrowers, indicating greater poverty outreach.

Following Servin, Lensink, and Van den Berg (2012), D'espallier, Goedecke, Hudon, and Mersland (2013) and Strøm, D'Espallier, and Mersland (2014), we control for a battery of variables related to firm performance and MFI characteristics. Total Assets, namely total assets, and Age, classified as new, young and mature in our case, reflect the competitiveness of an MFI. Leverage, debt-to-equity ratio, shows the financial health of an MFI and Total Assets Growth shows the expansion speed of an MFI. Portfolio Yield, the interest revenue (or markup and dividend revenue) divided by gross loan portfolio, mirrors an MFI's loan portfolio scale and output. Deposits-to-Assets ratio reflects the importance of deposits in an MFI's operation. Target Market, classified as low-end, high-end, small business and broad, reflects the business strategy of an MFI. For Regulated is a dummy variable if an MFI is regulated. Differences in legal status reflect different rights and duties in conducting businesses. For Profit is a dummy variable if an MFI targets at making profits rather than fulfilling social mission. Disclosure Ratings by the MIX Market database range from one to five, which implies the increasing disclosure quality. Number of Offices indicates firm competitiveness from a personnel perspective. The definitions of all measures are presented in Appendix A. 


\subsection{Descriptive statistics}

In Appendix C, we present data on 12 countries with both conventional and Islamic MFIs within the regions of South Asia, Middle East and North Africa, and Eastern Europe and Central Asia. These 12 countries are Afghanistan, Bangladesh, Indonesia, Iraq, Jordan, Kosovo, Kyrgyzstan, Lebanon, Pakistan, Palestine, Syria and Yemen (Appendix D). Table 1 reports descriptive statistics for all variables. To minimise the impact of outliers, we winsorize the continuous variables at one percentile level. We find that $12.50 \%$ of the observations are linked to Islamic MFIs and $87.50 \%$ of the observations are related to conventional MFIs.

The last column presents the comparison of conventional and Islamic MFIs in terms of the means of all variables. Islamic MFIs exhibit much higher operational costs than conventional MFIs. Overall, Islamic MFIs have a negative mean of ROA (-3.316\%) while conventional MFIs have a positive mean of ROA $(0.084 \%)$. The median of Islamic MFIs' ROA is $1.100 \%$, suggesting that over half of Islamic MFIs generate profits. This evidence is line with our expectation that Islamic MFIs are less profitable and less self-sufficient than conventional MFIs.

The remaining dependent variables, such as administrative costs, OSS, PaR $>90$, writeoff ratio, loan loss rate, number of active borrowers and average loan size, do not show a significant difference between conventional and Islamic MFIs. Both conventional and Islamic MFIs' mean values of OSS are above $110 \%$, indicating that both types of MFIs are on average operationally and financially self-sufficient.

Islamic MFIs are younger and smaller than conventional MFIs. The average total assets of both conventional and Islamic MFIs are around $\$ 500$ million, although Islamic MFIs are slightly smaller than conventional MFIs. Both conventional and Islamic MFIs have high leverage (no less than 400\%), although Islamic MFIs have higher leverage than conventional MFIs. Islamic MFIs are less likely to be legally regulated and profit-oriented than conventional MFIs. Islamic MFIs have higher deposits-to-assets ratios, and more offices, since they are restricted to invest in other assets (such as bonds) by Sharia. Islamic MFIs exhibit lower disclosure quality than conventional MFIs because, being relatively smaller and younger, Islamic MFIs have not developed qualified financial reporting systems. Differences between total assets growth, gross loan portfolio, portfolio yield and target market are insignificant between these two kinds of MFIs. 


\section{[Insert Table 1 here]}

\section{Empirical results}

\subsection{Financial performance}

Table 2 reports estimates from the baseline regressions. In Columns (1) and (2), Islamic MFI is significantly and positively associated with Operational Costs and Administrative Costs at the $1 \%$ level and 5\% level respectively. This evidence reflects the economically significant difference between these two costs for the two types of MFIs. For instance, the coefficient of Islamic MFI on Operational Costs (0.093) indicates that the operational costs of Islamic MFIs are 0.093 higher than those of conventional MFIs, which account for $59 \%$ of the average operational costs of the total sample (0.157). This result supports our expectation that the assets-involved Islamic MFIs' financial products create higher operational and administrative costs. In Columns (3) and (4), Islamic MFI is negatively and significantly related to ROA and $O S S$ at the $1 \%$ level. The difference in financial performance are also economically significant. For instance, the coefficient of Islamic MFI on OSS (-0.098) indicates that Islamic MFIs' OSS is 0.098 lower than that of conventional MFIs, which accounts for $8.60 \%$ of the average OSS of the total sample (1.140). Our result hence provides evidence to support our hypothesis (H1b) that Islamic MFIs are less profitable and less self-sufficient than conventional MFIs.

In terms of control variables, with the growth of firm size, ROA, operational costs and administrative costs are increasing, in line with those reported in Mersland and Strøm (2009), D'espallier, Goedecke, Hudon, and Mersland (2013) and Roberts (2013). When MFIs grow older, their operational and administrative costs increase accordingly. Portfolio yield is positively related to both costs and performance. Write-off ratio could lead to the increase of costs and the decrease of profitability and sustainability, in accordance with that reported in Strøm, D'Espallier, and Mersland (2014). Compared with MFIs targeting at broad markets, MFIs targeting at low-end markets have higher costs and lower performance, while MFIs targeting at small businesses have lower costs and lower performance. Regulating MFIs could increase their costs as well as their performance and disclosing ratings could increase both two costs. Profit-orientated MFIs tend to have lower administrative costs and MFIs with more offices tend to have higher ROA.

\section{[Insert Table 2 here]}




\subsection{Credit risk}

Table 3 reports estimates from the baseline regressions. Columns (1) to (3) show that Islamic MFI is negatively and significantly associated with PaR $>90$ days, Write-off Ratio and Loan Loss Rate at the 5\% level. These results are also economically significant. For instance, the coefficient of Islamic MFI (-0.017) on PaR>90days indicates that the percentage of loans overdue more than 90 days is 0.017 lower than that of conventional MFIs, which accounts for $35.42 \%$ of the average value of the total sample (0.048). In accordance with our hypothesis (H2a), our result shows that Islamic MFIs bear a lower credit risk than conventional MFIs. This evidence also suggests that although the complexity and penalty-free of Islamic financial products could bring about credit risk, religious belief encourages Muslim borrowers to fulfil their obligations under Islamic loan contracts and equity-like and risk-sharing nature of Islamic financial products increase the controlling and monitoring of borrowers, resulting in overall lower credit risk (Abedifar, Molyneux, and Tarazi, 2013; Baele, Farooq, and Ongena, 2014).

In terms of control variables, larger MFIs overall have higher credit risk. New MFIs have more loans that are overdue more than 90 days but have lower write-off ratio. Both leverage and total assets growth could increase MFIs' credit risk. Deposit-to-assets is positively related to the percentage of loans that are overdue more than 90 days, while is negatively related to the loan loss rate. MFIs, targeting at small business markets, have lower percentage of overdue loans. Both regulated and for-profit MFIs have higher loan loss rate. More offices increase the percentage of overdue loans. This evidence regarding control variables is consistent with that reported in Mersland and Strøm (2009) and D'espallier, Goedecke, Hudon, and Mersland (2013).

\section{[Insert Table 3 here]}

\subsection{Outreach}

We argue that an MFI has better outreach if it reaches more active borrowers. The number of active borrowers not only reflects the breadth of the outreach (how many poor people are served), but also the depth of outreach (how poor are the people served), because, holding the total lending constant, the poverty level of the borrowers an MFI can reach is inversely related with the total number of borrowers. A socially responsible MFI will pursue the goal of reaching the poorest people while at the same time serving a large number of 
borrowers. We also use average loan size as another measure of outreach. Average loan size is the average loan size per borrower divided by country group national income per capita. Smaller loans are usually taken out by poorer borrowers, indicating greater outreach.

Column (1) in Table 4 presents that Islamic MFI is positively and significantly linked to Ln of Number of Active Borrowers at the 1\% level. The economic significance of this difference is also sizeable. The coefficient of Islamic MFI (0.191) suggests that Islamic MFIs have on average $19.1 \%$ more active borrowers than conventional MFIs. Column (2) presents that Islamic MFI is negatively and significantly linked to Average Loan Size at the $1 \%$ level. The economic significance of this difference is also sizeable. The coefficients of Islamic MFI (-0.368) suggest that Islamic MFIs have on average 36.8\% smaller loan size than conventional MFIs. This evidence is consistent with our hypothesis (H3) that Islamic MFIs have a better poverty outreach than conventional MFIs. However, average loan size may not be a good indicator of poverty outreach because it is not necessarily associated with borrower poverty. First, institutional characteristics, such as maximum loan size, risk management practices or regulatory boundaries of MFIs' operations, are stronger drivers of an MFI's average loan size than borrower poverty (Christen and Drake, 2002; Dunford, 2002). Second, small loans are not predominantly given to very poor borrowers, since less poor borrowers might also be interested in more flexible small loans (Christen and Drake, 2002; Dunford, 2002).

In terms of control variables, large MFIs lend to more active borrowers and increase their average loan size. New MFIs have less active borrowers and larger average loan size. Total assets growth also reduces the number of active borrowers, while portfolio yield reduces average loan size. MFIs targeting at low-end markets have more active borrowers and MFIs targeting at high-end markets have less active borrowers. Regulated MFIs have larger average loan size, but the condition for for-profit MFIs is reversed. Disclosure ratings indicate more active borrowers and smaller average loan size. MFIs with less offices tend to have more active borrowers. These results regarding control variables are in line with those reported in Tchuigoua (2015).

\section{[Insert Table 4 here]}




\subsection{Mission drift}

We finally investigate the difference between conventional and Islamic MFIs with regards to mission drift. Our baseline regression is exhibited below:

$$
\begin{aligned}
\text { Outreach }_{i, t}= & \alpha+\beta_{1} * \text { Islamic MFI }_{i, t}+\beta_{2} * \text { Islamic MFI }_{i, t} * \text { ROA }_{i, t} \\
& +\beta_{3} * \text { ROA }_{i, t}+\beta_{4} * \text { Controls }_{i, t}+\beta_{5} * \text { Country }_{i}+\beta_{6} * \text { Year }_{t} \\
& +\varepsilon_{i, t}(2)
\end{aligned}
$$

The coefficient of ROA, $\beta_{3}$, is expected to be negative and significant, meaning that an increase in profitability is linked to a decrease in poverty outreach, and hence 'mission drift'. The variable of primary interest is the interaction term Islamic MFI*ROA, which represents the difference between Islamic and conventional MFIs in the impact of ROA on outreach. If we conjecture that Islamic MFIs are less likely to experience 'mission drift', we would expect $\beta_{2}$ to be positive and significant, indicating that the negative relationship between ROA and outreach is less severe for Islamic MFIs.

Columns (3) to (4) in Table 4 report the results. Column (3) shows that $R O A$ is negatively related to Ln of Number of Active Borrowers at the 5\% level. The coefficient of ROA $(-0.748)$ suggests that a $1 \%$ increase of MFIs' ROA leads to a $0.75 \%$ decrease of number of active borrowers. The interaction term Islamic $M F I^{*} R O A$ is positively and significantly related to Ln of Number of Active Borrowers at the 1\% level. This result suggests that the negative relation between ROA and poverty outreach is less obvious for Islamic MFIs, so Islamic MFIs are less likely to experience 'mission drift' than conventional MFIs. Column (4) shows that $R O A$ is positively related to Average Loan Size at the 5\% level. The coefficient of ROA (0.631) suggests that a $1 \%$ increase in MFIs' ROA leads to a $0.63 \%$ increase of average loan size. Since a larger Average Loan Size indicates less poverty outreach, an increase in profitability is related to a decrease in poverty outreach, which causes 'mission drift'. The interaction term Islamic $M F I^{*} R O A$ is negatively and significantly related to Average Loan Size at the 5\% level. This result also indicates that the negative relation between ROA and poverty outreach is less obvious for Islamic MFIs. These two results confirm our hypothesis H4 that compared with conventional MFIs, Islamic MFIs experience less 'mission drift'. 


\subsection{Robustness Checks}

The unbalanced sample, where the number of conventional MFIs is almost ten times of that of Islamic MFIs, might drive our results. To address the potential concern of selection bias, we use propensity score matching (PSM) method. This method could help us reject the competing explanation that our results spuriously reflect other different characteristics between Islamic MFIs and conventional MFIs, such as leverage and deposits-to-assets, rather than ones that we attempt to investigate, such as ROA and OSS. Specifically, using a one-to-one matching method without replacement, for each of the 35 Islamic MFIs, we select one conventional MFI that is closest to it according to observable characteristics (all control variables). In particular, for each hypothesis, the matching MFI selected is the conventional MFI with the closest propensity score, estimated from a linear regression of Islamic MFI on all control variables used in the corresponding specification ${ }^{5}$. This procedure results in a matched sample of 70 MFIs, where the treatment and control groups are overall statistically indifferent based on MFI characteristics. We rerun our main regressions using these matched samples in Table 5. We obtain similar results across all specifications.

\section{[Insert Table 5 here]}

\section{Conclusion}

It is hard for conventional MFIs to penetrate into regions with a substantial Muslim population because they are incompatible with the financial principles in Sharia (Islamic law), (Karim, Tarazi, and Reille, 2008). The high demand for loans highlights the need to provide religiously compatible products to the underserved Muslim poor, resulting in the advent of Islamic microfinance as a new market niche (Karim, Tarazi, and Reille, 2008). However, little is known about the actual performance or outcome of Islamic MFIs, which is the central focus of this paper. We expect that the Sharia-compliance characteristics play a role in mitigating the information asymmetry between Islamic MFIs and their borrowers due to the role of religiosity and the special product design. According to this hypothesis, we should expect that Islamic MFIs are less profitable and financially self-sufficient, have lower credit risk, have better poverty outreach and are less likely to have 'mission drift', than conventional MFIs. Employing a sample of microfinance institutions from three regions in the world for the period

\footnotetext{
${ }^{5}$ For instance, for hypothesis one (H1), the control variables used to calculate propensity score are those reported in Table 2.
} 
1998 to 2014, we find empirical evidence to support these predictions. Our results hold when we use PSM method.

Our study sheds light on extant literature from two perspectives. First, our research adds to the limited empirical literature on the role of Islamic finance in the economy and comparative literature between conventional and Islamic finance. Second, our research extends and complements the current literature on microfinance. In response to Mersland, D'Espallier, and Supphellen (2013)'s call for microfinance research that take religions into consideration, our research is the first study that investigates the impact of Islam on microfinance. This paper helps both practitioners and investors to gain a comprehensive understanding of the difference between conventional and Islamic MFIs. This study also has policy implications for governments in the Muslim world aiming to tackle national poverty in their nations/societies. 


\section{Reference}

Abdelsalam, O., Fethi, M. D., Matallín, J. C., Tortosa-Ausina, E., 2014. On the comparative performance of socially responsible and Islamic mutual funds. Journal of Economic Behavior and Organization 103, 108-128.

Abedifar, P., Hasan, I., Tarazi, A., 2016. Finance-growth nexus and dual-banking systems: Relative importance of Islamic banks. Journal of Economic Behavior and Organization 131, 198-215.

Abedifar, P., Molyneux, P., Tarazi, A., 2013. Risk in Islamic banking. Review of Finance 17(6), 2035-2096.

Adhikari, B. K., Agrawal, A., 2016. Does local religiosity matter for bank risk-taking? Journal of Corporate Finance 38, 272-293.

Aggarwal, R. K., Yousef, T., 2000. Islamic banks and investment financing. Journal of Money, Credit and Banking 32(1), 93-120.

Ahlin, C., Lin, J., Maio, M., 2011. Where does microfinance flourish? Microfinance institution performance in macroeconomic context. Journal of Development Economics 95(2), 105120.

Ahmed, A., Grace, L., 2001. Islamic banking principles applied to microfinance, case study: Hodeidah microfinance program, Yemen. Special Unit for Microfinance, New York.

Ahmed, E.M., Ammar, A., 2015. Islamic microfinance in Sudanese perspective. Journal of Business \& Financial Affairs 4, 149-154.

Alzahrani, M., 2019. Islamic corporate finance, financial markets, and institutions: An overview. Journal of Corporate Finance 55(C), 1-5.

Baele, L., Farooq, M., Ongena, S., 2014. Of religion and redemption: Evidence from default on Islamic loans. Journal of Banking \& Finance 44, 141-159.

Beck, T., Demirgüç-Kunt, A., Singer, D., 2013. Is small beautiful? Financial structure, size and access to finance. World Development 52, 19-33.

Biswas, S., 2010. India's micro-finance suicide epidemic. BBC NEWS, available at: http://www.bbc.co.uk/news/world-south-asia-11997571 (Last accessed at: 14/10/2017).

Bogan, V.L., 2012. Capital structure and sustainability: An empirical study of microfinance institutions. Review of Economics and Statistics 94(4), 1045-1058.

Brammer, S., Williams, G., Zinkin, J., 2007. Religion and attitudes to corporate social responsibility in a large cross-country sample. Journal of Business Ethics 71(3), 229-243. 
Callen, J. L., Fang, X., 2015. Religion and stock price crash risk. Journal of Financial and Quantitative Analysis 50(1-2), 169-195.

Caudill, S. B., Gropper, D. M., Hartarska, V., 2009. Which microfinance institutions are becoming more cost effective with time? Evidence from a mixture model. Journal of Money, Credit and Banking 41(4), 651-672.

Christen, R.P., Drake, D., 2002. Commercialization: The new reality of microfinance. In Drake, D., Rhyne, E., (Ed.), The commercialization of microfinance: Balancing business and development. Kumarian Press, Bloomfield, pp. 2-22.

Čihák, M., Hesse, H., 2010. Islamic banks and financial stability: An empirical analysis. Journal of Financial Services Research 38(2-3), 95-113.

Conroy, S. J., Emerson, T. L., 2004. Business ethics and religion: Religiosity as a predictor of ethical awareness among students. Journal of Business Ethics 50(4), 383-396.

Cull, R., Demirgüç-Kunt, A., Morduch, J., 2007. Financial performance and outreach: A global analysis of leading microbanks. The Economic Journal 117(517), 107-133.

D’Espallier, B., Hudon, M., Szafarz, A., 2013. Unsubsidized microfinance institutions, Economics Letters 120(2), 174-176.

Dehejia, R., Montgomery, H., Morduch, J., 2012. Do interest rates matter? Credit demand in the Dhaka slums. Journal of Development Economics 97(2), 437-449.

Derigs, U., Marzban, S., 2009. New strategies and a new paradigm for Shariah-compliant portfolio optimization. Journal of Banking \& Finance 33(6), 1166-1176.

Dichter, T. W., Harper, M., 2007. What's wrong with microfinance? Practical Action Publishing, Rugby.

Dunford, C., 2002. What's Wrong with Loan Size? Freedom from Hunger, Davis.

Eisfeldt, A. L., Rampini, A. A. 2009. Financing shortfalls and the value of aggregate liquidity. Unpublished working paper. Duke University and Northwestern University.

El-Ouadghiri, I., Peillex, J., 2018. Public attention to "Islamic terrorism" and stock market returns. Journal of Comparative Economics 46(4), 936-946.

El-Zoghbi, M., Tarazi, M., 2013. Trends in Sharia-Compliant Financial Inclusion. Published Business Reporting. CGAP, Washington, DC.

Galema, R., Lensink, R., Spierdijk, L., 2011. International diversification and microfinance, Journal of International Money and Finance 30(3), 507-515.

Gheeraert, L., 2014. Does Islamic finance spur banking sector development? Journal of Economic Behaviour and Organization 103, 4-20. 
Girona, E.F., Aghina, G., Boundaoui, I., 2014, Islamic microfinance in Yemen, Egypt and Indonesia, Unpublished Working Paper. Autonomous University of Madrid

Gutiérrez-Nieto, B., Serrano-Cinca, C., Molinero, C. M., 2009. Social efficiency in microfinance institutions. Journal of The Operational Research Society 60(1), 104-119.

Hartarska, V., Shen, X., Mersland, R., 2013. Scale economies and input price elasticities in microfinance institutions. Journal of Banking \& Finance 37(1), 118-131.

Hermes, N., Lensink, R., Meesters, A., 2011. Outreach and efficiency of microfinance institutions. World Development 39(6), 938-948.

Hilary, G., Hui, K.W., 2009. Does religion matter in corporate decision making in America? Journal of Financial Economics 93(3), 455-473.

Iqbal, M., Llewellyn, D.T., 2002. Islamic Banking and Finance: New Perspectives on ProfitSharing and Risk. Edward Elgar Publishing, UK.

Islam, A., Nguyen, C., Smyth, R., 2015. Does microfinance change informal lending in village economies? Evidence from Bangladesh. Journal of Banking \& Finance 50, 141-156.

Jahan, S., 2012. Poverty reduction scaling up local innovations for transformational change, Unpublished Organization Reporting. The United Nations Development Programme, New York.

Jiang, F., John, K., Li, C. W., Qian, Y., 2016. Earthly reward to the religious: Religiosity and the cost of public and private debt. Journal of Financial Quantitative and Analysis, forthcoming.

Kanagaretnam, K., Lobo, G. J., Wang, C., 2015. Religiosity and earnings management: International evidence from the banking industry. Journal of Business Ethics 132(2), 277296.

Karim, N., Tarazi, M., Reille, X., 2008. Islamic Microfinance: An Emerging Market Niche. Published Business Reporting. CGAP, Washington, DC.

Karim, R.A.A., 2001. International accounting harmonization, banking regulation, and Islamic banks. The International Journal of Accounting 36(2), 169-193.

Kleynjans, L., Hudon, M., 2016. A study of codes of ethics for Mexican microfinance institutions. Journal of Business Ethics 134(3), 397-412.

Kustin, B., 2015. Islamic (micro)finance culture, context, promise and challenges. Published Business Reporting. Bill \& Melinda Gates Foundation, Washington, DC.

Leventis, S., Dedoulis, E., Abdelsalam, O., 2015. The impact of religiosity on audit pricing. Journal of Business Ethics, 1-26.

Louis, P., Seret, A., Baesens, B., 2013. Financial efficiency and social impact of microfinance institutions using self-organizing maps. World Development 46, 197-210. 
Mallin, C., Farag, H., Ow-Yong, K., 2014. Corporate social responsibility and financial performance in Islamic banks. Journal of Economic Behaviour and Organization 103, 2138.

McGuire, S. T., Omer, T. C., Sharp, N. Y., 2011. The impact of religion on financial reporting irregularities. The Accounting Review 87(2), 645-673.

McIntosh, C., Janvry, A., Sadoulet, E., 2005. How rising competition among microfinance institutions affects incumbent lenders. The Economic Journal 115(506), 987-1004.

Mersland, R., D'Espallier, B., Supphellen, M., 2013. The effects of religion on development efforts: Evidence from the microfinance industry and a research agenda. World Development 41, 145-156.

Mersland, R., Strøm, R.Ø., 2009. Performance and governance in microfinance institutions. Journal of Banking \& Finance 33(4), 662-669.

Mohieldin, M., Iqbal, Z., Rostom, A. M., Fu, X., 2011. The role of Islamic finance in enhancing financial inclusion in Organization of Islamic Cooperation (OIC) countries. Unpublished Working Paper. World Bank Group.

Navajas, S., Conning, J., Gonzalez-Vega, C., 2003. Lending technologies, competition and consolidation in the market for microfinance in Bolivia. Journal of International Development 15(6), 747-770.

Obaidullah, M., Khan, T., 2008. Islamic microfinance development: Challenges and initiatives. Unpublished Working Paper. Islamic Development Bank.

Obid, S.N.S., Naysary, B., 2014. Toward a comprehensive theoretical framework for Shariah governance in Islamic financial institutions. Journal of Financial Services Marketing 19(4), 304-318.

Randøy, T., Strøm, R. Ø., Mersland, R., 2015. The Impact of Entrepreneur-CEOs in Microfinance Institutions: A Global Survey. Entrepreneurship Theory and Practice 39(4), 927-953.

Roberts, P.W., 2013. The profit orientation of microfinance institutions and effective interest rates. World Development 41, 120-131.

Seibel, H.D., 2011. Islamic Microfinance in Indonesia: The Challenge of Institutional Diversity, Regulation and Supervision. In Nazim Ali, S., (Ed.), Sharia-Compliant Microfinance. Routledge, London. pp. 147-69.

Servin, R., Lensink, R., Van den Berg, M., 2012. Ownership and technical efficiency of microfinance institutions: Empirical evidence from Latin America. Journal of Banking \& Finance 36(7), 2136-2144. 
Shu, T., Sulaeman, J., Yeung, P. E., 2012. Local religious beliefs and mutual fund risk-taking behaviors. Management Science 58(10), 1779-1796.

Strøm, R. Ø., D’Espallier, B., Mersland, R., 2014. Female leadership, performance, and governance in microfinance institutions. Journal of Banking \& Finance 42, 60-75.

Sundaresan, S., 2008. Microfinance Emerging Trends and Challenges. Edward Elgar, Cheltenham, UK.

Tchuigoua, H. T., 2015. Capital structure of microfinance institutions. Journal of Financial Services Research 47(3), 313-340.

Terpstra, D.E., Rozell, E.J., Robinson, R.K., 1973. The influence of personality and demographic variables on ethical decisions related to insider trading. The Journal of Psychology 127(4), 375-389.

Yanikkaya, H., Gumus, N., Pabuccu, Y. U., 2018. How profitability differs between conventional and Islamic banks: A dynamic panel data approach. Pacific-Basin Finance Journal 48, 99111. 
Table 1

Summary Statistics

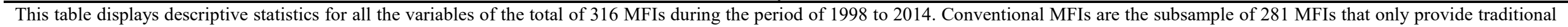

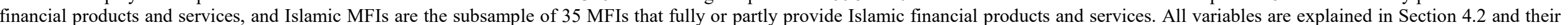
formal definitions are presented in Appendix A.

\begin{tabular}{|c|c|c|c|c|c|c|c|c|c|c|}
\hline \multirow[b]{2}{*}{ Variables } & \multicolumn{3}{|c|}{ All MFIs } & \multicolumn{3}{|c|}{ Conventional MFIs } & \multicolumn{3}{|c|}{ Islamic MFIs } & \multirow[b]{2}{*}{$\begin{array}{c}\text { Mean } \\
\text { Difference }\end{array}$} \\
\hline & Mean & SD & $\mathbf{N}$ & Mean & SD & $\mathbf{N}$ & Mean & SD & $\mathbf{N}$ & \\
\hline \multicolumn{11}{|l|}{ Key Variable } \\
\hline Islamic MFI & 0.125 & 0.382 & 1945 & & & & & & & \\
\hline \multicolumn{11}{|l|}{ Dependent Variables } \\
\hline Operational Costs (\%) & 15.734 & 11.042 & 1495 & 15.347 & 10.844 & 1260 & 17.809 & 11.587 & 235 & $2.382 * * *$ \\
\hline Administrative Costs (\%) & 6.474 & 5.232 & 1495 & 6.385 & 5.115 & 1260 & 6.955 & 5.736 & 235 & 0.570 \\
\hline ROA $(\%)$ & -0.341 & 16.141 & 1945 & 0.084 & 14.731 & 1702 & -3.316 & 18.002 & 243 & $-3.400 * * *$ \\
\hline OSS (\%) & 113.935 & 51.832 & 1945 & 112.532 & 53.845 & 1702 & 123.767 & 42.752 & 243 & 11.235 \\
\hline $\mathrm{PaR}>90$ days $(\%)$ & 4.879 & 8.432 & 1945 & 4.782 & 9.423 & 1702 & 5.556 & 4.856 & 243 & 0.774 \\
\hline Write-off Ratio (\%) & 1.692 & 6.723 & 1945 & 1.712 & 7.312 & 1702 & 1.555 & 5.387 & 243 & -0.157 \\
\hline Loan Loss Rate (\%) & 1.691 & 4.112 & 1945 & 1.713 & 4.214 & 1702 & 1.538 & 2.945 & 243 & -0.175 \\
\hline $\begin{array}{l}\text { Ln (Number of Active } \\
\text { Borrowers) }\end{array}$ & 7.930 & 49.285 & 1945 & 9.019 & 50.456 & 1702 & 0.305 & 1.659 & 243 & -8.714 \\
\hline Average Loan Size & 1.457 & 0.531 & 1945 & 1.582 & 0.548 & 1702 & 0.585 & 0.050 & 243 & -0.997 \\
\hline \multicolumn{11}{|l|}{ Control Variables } \\
\hline Ln(Total Assets) & 15.454 & 2.125 & 1945 & 15.508 & 2.227 & 1702 & 15.073 & 1.859 & 243 & $-0.435^{* * *}$ \\
\hline Age_Mature & 0.636 & 0.485 & 1945 & 0.658 & 0.474 & 1702 & 0.478 & 0.500 & 243 & $-0.180 * * *$ \\
\hline Age New & 0.167 & 0.402 & 1945 & 0.155 & 0.362 & 1702 & 0.252 & 0.435 & 243 & $0.097 *$ \\
\hline Leverage $(\%)$ & 443.517 & 7518.932 & 1945 & 435.322 & 7786.849 & 1702 & 500.918 & 6704.084 & 243 & $65.596^{* * *}$ \\
\hline Total Assets Growth (\%) & 300.000 & 5104.928 & 1945 & 336.637 & 5748.606 & 1702 & 45.064 & 79.234 & 243 & -291.573 \\
\hline Portfolio Yield (\%) & 28.578 & 12.643 & 1945 & 28.676 & 10.274 & 1702 & 27.889 & 14.234 & 243 & -0.787 \\
\hline Deposits-to-Assets (\%) & 24.794 & 31.628 & 1945 & 23.517 & 31.694 & 1702 & 33.740 & 31.038 & 243 & $10.223 *$ \\
\hline Target Market_Low End & 0.332 & 0.470 & 1945 & 0.338 & 0.473 & 1702 & 0.286 & 0.413 & 243 & -0.052 \\
\hline Target Market_High End & 0.055 & 0.224 & 1945 & 0.053 & 0.223 & 1702 & 0.068 & 0.252 & 243 & 0.015 \\
\hline $\begin{array}{l}\text { Target Market_Small } \\
\text { Business }\end{array}$ & 0.049 & 0.217 & 1945 & 0.050 & 0.217 & 1702 & 0.041 & 0.199 & 243 & -0.008 \\
\hline For Regulated & 0.665 & 0.465 & 1945 & 0.689 & 0.463 & 1702 & 0.500 & 0.501 & 243 & $-0.450 * * *$ \\
\hline For Profit & 0.428 & 0.491 & 1945 & 0.437 & 0.496 & 1702 & 0.362 & 0.478 & 243 & $-0.075^{*}$ \\
\hline Disclosure Ratings & 2.592 & 1.414 & 1945 & 2.594 & 1.367 & 1702 & 2.581 & 1.443 & 243 & $-0.013 * * *$ \\
\hline Ln (Number of Offices) & 2.434 & 185 & 1945 & 2.297 & 1.397 & 1702 & 3.391 & 1.275 & 243 & $1.094 * * *$ \\
\hline
\end{tabular}


Table 2

Financial Performance

This table reports panel regression results of financial performance on Islamic MFIs in the sample period 1998 to 2014 . For dependent variables, Operational Costs are the operational costs divided by the gross loan portfolio. Administrative Costs are the total administrative costs on the loan portfolio divided by the total assets. ROA is the ratio of net operating income to total assets. Operating Self-Sufficiency $(O S S)$ is defined as total financial revenue divided by the sum of financial expense, operating expense and loan loss provision expense. The independent variable Islamic MFI is a dummy variable which equals one if an MFI is Islamic, and 0 if it is conventional. Definitions of all variables are shown in Appendix A. In all columns, country-fixed and year-fixed effects are further controlled. Standard errors are clustered at the firm level and are shown in parentheses, $* * *$ and $* * *$ denote statistical significance at the $10 \%, 5 \%$ and $1 \%$ level, respectively.

\begin{tabular}{|c|c|c|c|c|}
\hline Dependent Variables & Operational Costs & $\begin{array}{c}\text { Administrative } \\
\text { Costs }\end{array}$ & ROA & OSS \\
\hline & $(1)$ & $(2)$ & $(3)$ & $(4)$ \\
\hline Islamic MFI & $\begin{array}{c}0.093 * * * \\
(2.71)\end{array}$ & $\begin{array}{c}0.016^{* * *} \\
(1.96)\end{array}$ & $\begin{array}{c}-0.037 * * * \\
(-2.63)\end{array}$ & $\begin{array}{c}-0.098 * * * \\
(-2.84)\end{array}$ \\
\hline Ln(Total Assets) & $\begin{array}{c}0.521 * * * \\
(10.57)\end{array}$ & $\begin{array}{c}0.481 * * * \\
(11.57)\end{array}$ & $\begin{array}{c}0.025^{* *} \\
(2.56)\end{array}$ & $\begin{array}{l}0.030 \\
(0.84)\end{array}$ \\
\hline Age_Mature & $\begin{array}{c}-0.226 * * * \\
(-7.79)\end{array}$ & $\begin{array}{c}-0.151 * * * \\
(-4.64)\end{array}$ & $\begin{array}{l}-0.001 \\
(-0.24)\end{array}$ & $\begin{array}{l}-0.072 \\
(-1.39)\end{array}$ \\
\hline Age_New & $\begin{array}{l}0.058 \\
(1.43)\end{array}$ & $\begin{array}{c}0.084^{*} \\
(1.71)\end{array}$ & $\begin{array}{c}-0.046^{* * * *} \\
(-5.24)\end{array}$ & $\begin{array}{c}-0.037 * * * \\
(-4.14)\end{array}$ \\
\hline Leverage & $\begin{array}{l}-0.000 \\
(-1.18)\end{array}$ & $\begin{array}{l}-0.000 \\
(-0.66)\end{array}$ & $\begin{array}{c}0.000 \\
(-0.13)\end{array}$ & $\begin{array}{c}0.000 \\
(-0.47)\end{array}$ \\
\hline Total Assets Growth & $\begin{array}{l}0.000 \\
(1.11)\end{array}$ & $\begin{array}{c}0.001 * * * \\
(8.97)\end{array}$ & $\begin{array}{l}0.000 \\
(1.39)\end{array}$ & $\begin{array}{c}0.000 \\
(-1.21)\end{array}$ \\
\hline Portfolio Yield & $\begin{array}{c}0.123 * * * \\
(3.67)\end{array}$ & $\begin{array}{c}0.102^{* * *} \\
(3.12)\end{array}$ & $\begin{array}{c}0.147 * * * \\
(3.20)\end{array}$ & $\begin{array}{c}0.425^{* * *} \\
(2.91)\end{array}$ \\
\hline Deposits-to-Assets & $\begin{array}{l}0.060 \\
(1.38)\end{array}$ & $\begin{array}{l}0.046 \\
(0.90)\end{array}$ & $\begin{array}{l}-0.005 \\
(-0.54)\end{array}$ & $\begin{array}{l}-0.002 \\
(-0.25)\end{array}$ \\
\hline Write-off Ratio & $\begin{array}{c}1.622 * * * \\
(4.11)\end{array}$ & $\begin{array}{c}0.802^{* * *} \\
(3.01)\end{array}$ & $\begin{array}{c}-0.226^{* *} \\
(-2.29)\end{array}$ & $\begin{array}{c}-1.300^{* * * *} \\
(-3.02)\end{array}$ \\
\hline Target Market_Low End & $\begin{array}{l}0.004 \\
(1.05)\end{array}$ & $\begin{array}{c}0.005^{* * * *} \\
(2.58)\end{array}$ & $\begin{array}{c}-0.011 * * * \\
(-3.19)\end{array}$ & $\begin{array}{l}0.006 \\
(1.56)\end{array}$ \\
\hline Target Market_High End & $\begin{array}{l}-0.008 \\
(-1.40)\end{array}$ & $\begin{array}{l}-0.003 \\
(-1.13)\end{array}$ & $\begin{array}{l}0.001 \\
(0.12)\end{array}$ & $\begin{array}{l}-0.006 \\
(1.12)\end{array}$ \\
\hline Target Market_Small Business & $\begin{array}{c}-0.025^{* * *} \\
(-3.37)\end{array}$ & $\begin{array}{l}-0.000 \\
(-0.07)\end{array}$ & $\begin{array}{c}-0.021^{* * *} \\
(-2.59)\end{array}$ & $\begin{array}{c}-0.099^{* *} \\
(-2.18)\end{array}$ \\
\hline For Regulated & $\begin{array}{c}0.082 * * * \\
(3.00)\end{array}$ & $\begin{array}{c}0.142 * * \\
(1.98)\end{array}$ & $\begin{array}{c}0.051^{* *} \\
(2.34)\end{array}$ & $\begin{array}{l}-0.002 \\
(-0.78)\end{array}$ \\
\hline For Profit & $\begin{array}{l}-0.035 \\
(-0.92)\end{array}$ & $\begin{array}{c}-0.090^{*} \\
(-1.95)\end{array}$ & $\begin{array}{l}-0.004 \\
(-0.58)\end{array}$ & $\begin{array}{l}-0.004 \\
(-0.82)\end{array}$ \\
\hline Disclosure Ratings & $\begin{array}{c}0.061 * * * \\
(6.19)\end{array}$ & $\begin{array}{c}0.033^{* * * *} \\
(2.68)\end{array}$ & $\begin{array}{l}-0.003 \\
(-1.56)\end{array}$ & $\begin{array}{l}-0.002 \\
(-1.34)\end{array}$ \\
\hline Ln(Number of Offices) & $\begin{array}{l}-0.007 \\
(-0.40)\end{array}$ & $\begin{array}{l}-0.012 \\
(-0.61)\end{array}$ & $\begin{array}{l}0.006^{*} \\
(1.91)\end{array}$ & $\begin{array}{l}0.003 \\
(1.05)\end{array}$ \\
\hline Constant & $\begin{array}{l}-0.863^{*} \\
(-1.86)\end{array}$ & $\begin{array}{c}-1.008^{* * *} \\
(-4.17)\end{array}$ & $\begin{array}{c}-0.120^{* * * *} \\
(-3.09)\end{array}$ & $\begin{array}{c}-0.293^{* * * *} \\
(-7.15)\end{array}$ \\
\hline $\begin{array}{l}\text { Country Fixed Effects } \\
\text { Year Fixed Effects } \\
\mathrm{N} \\
\text { adj. } \mathrm{R}^{2}\end{array}$ & $\begin{array}{c}\text { Yes } \\
\text { Yes } \\
1495 \\
0.523 \\
\end{array}$ & $\begin{array}{c}\text { Yes } \\
\text { Yes } \\
1495 \\
0.532\end{array}$ & $\begin{array}{c}\text { Yes } \\
\text { Yes } \\
1945 \\
0.484 \\
\end{array}$ & $\begin{array}{c}\text { Yes } \\
\text { Yes } \\
1945 \\
0.333 \\
\end{array}$ \\
\hline
\end{tabular}


Table 3

Credit Risk

This table reports panel regression results of credit risk on Islamic MFIs in the sample period 1998 to 2014. For dependent variables, PaR $>90$ days is the percentage of the portfolio that is overdue for more than 90 days. Write-off Ratio is the percentage of the total amount of loans written off to gross loan portfolio. Loan Loss Rate is the ratio of the difference between write-offs and loans recovered to gross loan portfolio. The independent variable Islamic MFI is a dummy variable which equals one if an MFI is Islamic, and 0 if it is conventional. Definitions of all variables are shown in Appendix A. In all columns, country-fixed and year-fixed effects are further controlled. Standard errors are clustered at the firm level and are shown in parentheses, *, ** and *** denote statistical significance at the $10 \%, 5 \%$ and $1 \%$ level,

\begin{tabular}{|c|c|c|c|}
\hline Dependent Variables & PaR $>$ 90days & Write-off Ratio & Loan Loss Rate \\
\hline & $(1)$ & $(2)$ & $(3)$ \\
\hline Islamic MFI & $\begin{array}{c}-0.017 * * \\
(-2.04)\end{array}$ & $\begin{array}{c}-0.002 * * \\
(-1.97)\end{array}$ & $\begin{array}{c}-0.005 * * \\
(-2.06)\end{array}$ \\
\hline Ln(Total Assets) & $\begin{array}{l}-0.004 \\
(-0.74)\end{array}$ & $\begin{array}{c}0.037^{*} \\
(1.79)\end{array}$ & $\begin{array}{c}0.007 * * \\
(2.03)\end{array}$ \\
\hline Age_Mature & $\begin{array}{l}-0.001 \\
(-0.23)\end{array}$ & $\begin{array}{l}0.000 \\
(0.09)\end{array}$ & $\begin{array}{c}0.002 \\
(0.79)\end{array}$ \\
\hline Age_New & $\begin{array}{l}0.013^{*} \\
(1.76)\end{array}$ & $\begin{array}{c}-0.013^{* * *} \\
(-3.06)\end{array}$ & $\begin{array}{l}0.005 \\
(1.40)\end{array}$ \\
\hline Leverage & $\begin{array}{l}0.000 \\
(1.57)\end{array}$ & $\begin{array}{l}-0.000 \\
(-0.56)\end{array}$ & $\begin{array}{c}0.000 * * * \\
(3.17)\end{array}$ \\
\hline Total Assets Growth & $\begin{array}{l}0.000 \\
(0.84)\end{array}$ & $\begin{array}{c}0.000^{* *} \\
(2.27)\end{array}$ & $\begin{array}{c}0.000 * * * \\
(3.17)\end{array}$ \\
\hline Portfolio Yield & $\begin{array}{l}-0.004 \\
(-0.32)\end{array}$ & $\begin{array}{l}-0.015 \\
(-0.78)\end{array}$ & $\begin{array}{l}0.009 \\
(1.05)\end{array}$ \\
\hline Deposits-to-Assets & $\begin{array}{c}0.054 * * * \\
(5.44)\end{array}$ & $\begin{array}{l}0.007 \\
(1.36)\end{array}$ & $\begin{array}{c}-0.008^{* *} \\
(-2.28)\end{array}$ \\
\hline ROA & $\begin{array}{l}0.006 \\
(0.22)\end{array}$ & $\begin{array}{c}-0.072 * * * \\
(-3.58)\end{array}$ & $\begin{array}{l}-0.001 \\
(-0.12)\end{array}$ \\
\hline Target Market_Low End & $\begin{array}{l}-0.000 \\
(-0.04)\end{array}$ & $\begin{array}{l}0.000 \\
(0.01)\end{array}$ & $\begin{array}{l}-0.294 \\
(-1.03)\end{array}$ \\
\hline Target Market_High End & $\begin{array}{l}-0.006 \\
(-0.81)\end{array}$ & $\begin{array}{l}0.011 \\
(0.78)\end{array}$ & $\begin{array}{l}0.216 \\
(0.48)\end{array}$ \\
\hline Target Market_Small Business & $\begin{array}{c}-0.019 * * * \\
(-3.56)\end{array}$ & $\begin{array}{l}-0.001 \\
(-0.29)\end{array}$ & $\begin{array}{l}-0.100 \\
(-0.52)\end{array}$ \\
\hline For Regulated & $\begin{array}{l}0.007 \\
(0.59)\end{array}$ & $\begin{array}{l}0.005 \\
(1.27)\end{array}$ & $\begin{array}{c}0.011 * * * \\
(2.91)\end{array}$ \\
\hline For Profit & $\begin{array}{l}0.008 \\
(1.51)\end{array}$ & $\begin{array}{l}-0.001 \\
(-0.54)\end{array}$ & $\begin{array}{c}0.006^{* *} \\
(2.12)\end{array}$ \\
\hline Disclosure Ratings & $\begin{array}{l}-0.001 \\
(-0.73)\end{array}$ & $\begin{array}{l}0.001 \\
(0.88)\end{array}$ & $\begin{array}{l}-0.001 \\
(1.12)\end{array}$ \\
\hline Ln (Number of Offices) & $\begin{array}{c}0.008 * * * \\
(2.82)\end{array}$ & $\begin{array}{l}-0.001 \\
(-0.81)\end{array}$ & $\begin{array}{l}-0.001 \\
(-0.23)\end{array}$ \\
\hline Constant & $\begin{array}{c}0.080^{* * * *} \\
(3.12)\end{array}$ & $\begin{array}{c}0.053^{* *} \\
(2.18)\end{array}$ & $\begin{array}{l}-0.006 \\
(-0.42)\end{array}$ \\
\hline $\begin{array}{l}\text { Country Fixed Effects } \\
\text { Year Fixed Effects } \\
\mathrm{N} \\
\text { adj. } \mathrm{R}^{2}\end{array}$ & $\begin{array}{c}\text { Yes } \\
\text { Yes } \\
1945 \\
0.145 \\
\end{array}$ & $\begin{array}{l}\text { Yes } \\
\text { Yes } \\
1945 \\
0.128 \\
\end{array}$ & $\begin{array}{c}\text { Yes } \\
\text { Yes } \\
1945 \\
0.121 \\
\end{array}$ \\
\hline
\end{tabular}


Table 4

Social Performance: Outreach and Mission Drift

In this table, Columns (1) to (2) present panel regression results of poverty outreach on Islamic MFIs, and Columns (3) and (4) report panel regression results of mission drift on Islamic MFIs in the sample period 1998 to 2014. For dependent variables, Number of Active Borrowers reflects the total number of individuals that an MFI serves. Average Loan Size is the average loan size per borrower divided by country group national income per capita. The independent variable Islamic MFI is a dummy variable which equals one if an MFI is Islamic, and 0 if it is conventional. The interaction term Islamic MFI*ROA represents the effect of the Islamic MFI's ROA on poverty outreach, namely mission drift. Definitions of all variables are shown in Appendix A. In all columns, country-fixed and year-fixed effects are further controlled. Standard errors are clustered at the firm level and are shown in parentheses, ${ }^{*}, * *$ and $* * *$ denote statistical significance at the $10 \%, 5 \%$ and $1 \%$ level, respectively.

\begin{tabular}{|c|c|c|c|c|}
\hline Dependent Variables & $\begin{array}{c}\text { Ln(Number of } \\
\text { Active Borrowers) } \\
\end{array}$ & Average Loan Size & $\begin{array}{c}\text { Ln(Number of } \\
\text { Active Borrowers) } \\
\end{array}$ & Average Loan Size \\
\hline & $(1)$ & $(2)$ & $(3)$ & $(4)$ \\
\hline Dummy_Islamic MFI & $\begin{array}{c}0.191^{* * *} \\
(2.87)\end{array}$ & $\begin{array}{c}-0.368 * * * \\
(-2.96)\end{array}$ & $\begin{array}{c}0.202 * * * \\
(2.83)\end{array}$ & $\begin{array}{c}-0.066^{* * *} \\
(-2.98)\end{array}$ \\
\hline Dummy_Islamic MFIs*ROA & & & $\begin{array}{c}0.568 * * * \\
(3.28)\end{array}$ & $\begin{array}{c}-0.086^{* *} \\
(-2.43)\end{array}$ \\
\hline ROA & $\begin{array}{c}-0.609^{*} \\
(-1.85)\end{array}$ & $\begin{array}{c}0.056^{* *} \\
(2.11)\end{array}$ & $\begin{array}{c}-0.748 * * \\
(-2.18)\end{array}$ & $\begin{array}{c}0.631 * * \\
(2.14)\end{array}$ \\
\hline Ln(Total Assets) & $\begin{array}{c}0.801 * * \\
(-4.53)\end{array}$ & $\begin{array}{c}0.151 * * * \\
(8.26)\end{array}$ & $\begin{array}{c}0.800 * * * \\
(-4.58)\end{array}$ & $\begin{array}{c}0.151^{* * *} \\
(8.26)\end{array}$ \\
\hline Age_Mature & $\begin{array}{l}0.072 \\
(1.36)\end{array}$ & $\begin{array}{l}0.007 \\
(1.08)\end{array}$ & $\begin{array}{l}0.075 \\
(1.42)\end{array}$ & $\begin{array}{l}0.006 \\
(0.93)\end{array}$ \\
\hline Age_New & $\begin{array}{c}-0.152 * * \\
(-2.30)\end{array}$ & $\begin{array}{c}0.210^{* *} \\
(2.52)\end{array}$ & $\begin{array}{c}-0.148 * * \\
(-2.23)\end{array}$ & $\begin{array}{c}0.207 * * \\
(2.49)\end{array}$ \\
\hline Leverage & $\begin{array}{l}0.000 \\
(0.17)\end{array}$ & $\begin{array}{l}-0.000 \\
(-1.52)\end{array}$ & $\begin{array}{l}0.000 \\
(0.11)\end{array}$ & $\begin{array}{l}-0.000 \\
(-0.96)\end{array}$ \\
\hline Total Assets Growth & $\begin{array}{c}-0.001 * * * \\
(3.81)\end{array}$ & $\begin{array}{l}-0.000 \\
(-0.61)\end{array}$ & $\begin{array}{c}-0.001 * * * \\
(3.54)\end{array}$ & $\begin{array}{l}-0.000 \\
(-0.41)\end{array}$ \\
\hline Portfolio Yield & $\begin{array}{l}-0.010 \\
(-0.04)\end{array}$ & $\begin{array}{c}-0.026 * * * \\
(-2.87)\end{array}$ & $\begin{array}{l}0.041 \\
(0.14)\end{array}$ & $\begin{array}{c}-0.032 * * * \\
(-3.90)\end{array}$ \\
\hline Deposits-to-Assets & $\begin{array}{l}0.053 \\
(0.75)\end{array}$ & $\begin{array}{l}-0.007 \\
(-1.47)\end{array}$ & $\begin{array}{l}0.048 \\
(0.67)\end{array}$ & $\begin{array}{l}-0.005 \\
(-1.23)\end{array}$ \\
\hline Write-off Ratio & $\begin{array}{l}0.347 \\
(1.11)\end{array}$ & $\begin{array}{l}-0.047 \\
(-1.09)\end{array}$ & $\begin{array}{l}0.313 \\
(1.01)\end{array}$ & $\begin{array}{l}-0.038 \\
(-0.92)\end{array}$ \\
\hline Target Market_Low End & $\begin{array}{l}0.098^{*} \\
(1.79)\end{array}$ & $\begin{array}{l}-0.046 \\
(-1.25)\end{array}$ & $\begin{array}{l}0.096^{*} \\
(1.75)\end{array}$ & $\begin{array}{l}-0.044 \\
(-1.21)\end{array}$ \\
\hline Target Market_High End & $\begin{array}{l}-0.178^{*} \\
(-1.70)\end{array}$ & $\begin{array}{l}0.077 \\
(0.71)\end{array}$ & $\begin{array}{l}-0.179^{*} \\
(-1.71)\end{array}$ & $\begin{array}{l}0.076 \\
(0.70)\end{array}$ \\
\hline Target Market_Small Business & $\begin{array}{l}0.085 \\
(0.62)\end{array}$ & $\begin{array}{l}0.077 \\
(0.66)\end{array}$ & $\begin{array}{l}0.078 \\
(0.57)\end{array}$ & $\begin{array}{l}0.084 \\
(0.72)\end{array}$ \\
\hline For Regulated & $\begin{array}{l}-0.003 \\
(-1.25)\end{array}$ & $\begin{array}{c}0.008^{* *} \\
(2.23)\end{array}$ & $\begin{array}{l}-0.003 \\
(-1.21)\end{array}$ & $\begin{array}{c}0.008^{* *} \\
(2.28)\end{array}$ \\
\hline For Profit & $\begin{array}{l}0.063 \\
(1.22)\end{array}$ & $\begin{array}{c}-0.130 * * \\
(-2.17)\end{array}$ & $\begin{array}{l}0.063 \\
(1.21)\end{array}$ & $\begin{array}{c}-0.130 * * \\
(-2.04)\end{array}$ \\
\hline Disclosure Ratings & $\begin{array}{c}0.114^{* * *} \\
(7.12)\end{array}$ & $\begin{array}{c}-0.127 * * * \\
(-6.26)\end{array}$ & $\begin{array}{c}0.113^{* * *} \\
(7.05)\end{array}$ & $\begin{array}{c}-0.126^{* * *} \\
(-6.23)\end{array}$ \\
\hline Ln(Number of Offices) & $\begin{array}{c}-0.047^{*} \\
(-1.93)\end{array}$ & $\begin{array}{l}2.790 \\
(1.35)\end{array}$ & $\begin{array}{c}-0.047^{*} \\
(-1.93)\end{array}$ & $\begin{array}{l}2.644 \\
(1.28)\end{array}$ \\
\hline Constant & $\begin{array}{c}-3.543 * * * \\
(-11.42)\end{array}$ & $\begin{array}{c}-0.732 * * * \\
(2.90)\end{array}$ & $\begin{array}{c}-3.528 * * * \\
(-11.37)\end{array}$ & $\begin{array}{c}-0.702 * * * \\
(2.76)\end{array}$ \\
\hline Country Fixed Effects & Yes & Yes & Yes & Yes \\
\hline Year Fixed Effects & Yes & Yes & Yes & Yes \\
\hline $\mathrm{N}$ & 1945 & 1945 & 1945 & 1945 \\
\hline $\operatorname{adj} . R^{2}$ & 0.480 & 0.387 & 0.480 & 0.384 \\
\hline
\end{tabular}


Table 5

Financial Performance, Credit Risk and Social Performance: Propensity Score Matching (PSM) Analyses

\begin{tabular}{|c|c|c|c|c|}
\hline \multirow{2}{*}{\multicolumn{5}{|c|}{$\begin{array}{l}\text { This table reports panel regression } \mathrm{r} \\
\text { obtained from propensity score matc } \\
\text { Costs, ROA and OSS. Panel B presen } \\
\text { results using social performance me } \\
\text { in Appendix A. In all columns, cou } \\
\text { and are shown in parentheses, *,** } \\
\text { Panel A: Financial Performance }\end{array}$}} \\
\hline & & & & \\
\hline \multirow[t]{2}{*}{ Dependent Variables } & Operational Costs & $\begin{array}{c}\text { Administrative } \\
\text { Costs }\end{array}$ & ROA & OSS \\
\hline & $(1)$ & $(2)$ & (3) & $(4)$ \\
\hline Islamic MFI & $\begin{array}{c}0.052^{* *} \\
(2.11)\end{array}$ & $\begin{array}{c}0.026^{* *} \\
(2.03)\end{array}$ & $\begin{array}{c}-0.042^{* *} \\
(-2.45)\end{array}$ & $\begin{array}{c}-0.082 * * * \\
(-2.96)\end{array}$ \\
\hline $\begin{array}{l}\text { Controls } \\
\text { Country Fixed Effects } \\
\text { Year Fixed Effects } \\
\mathrm{N} \\
\text { adj. } \mathrm{R}^{2}\end{array}$ & $\begin{array}{l}\text { Yes } \\
\text { Yes } \\
\text { Yes } \\
470 \\
0.368 \\
\end{array}$ & $\begin{array}{c}\text { Yes } \\
\text { Yes } \\
\text { Yes } \\
470 \\
0.264 \\
\end{array}$ & $\begin{array}{c}\text { Yes } \\
\text { Yes } \\
\text { Yes } \\
486 \\
0.358 \\
\end{array}$ & $\begin{array}{l}\text { Yes } \\
\text { Yes } \\
\text { Yes } \\
486 \\
0.221 \\
\end{array}$ \\
\hline \multicolumn{5}{|l|}{ Panel B: Credit Risk } \\
\hline Dependent Variables & $\begin{array}{c}\text { PaR }>\text { 90days } \\
(1)\end{array}$ & $\begin{array}{c}\text { Write-off Ratio } \\
(2)\end{array}$ & $\frac{\text { Loan Loss Rate }}{(3)}$ & \\
\hline Islamic MFI & $\begin{array}{c}-0.021 * * \\
(-2.12)\end{array}$ & $\begin{array}{l}-0.004^{*} \\
(-1.84)\end{array}$ & $\begin{array}{l}-0.005^{*} \\
(-1.81)\end{array}$ & \\
\hline $\begin{array}{l}\text { Controls } \\
\text { Country Fixed Effects } \\
\text { Year Fixed Effects } \\
\mathrm{N} \\
\text { adj. } \mathrm{R}^{2} \\
\end{array}$ & $\begin{array}{l}\text { Yes } \\
\text { Yes } \\
\text { Yes } \\
486 \\
0.498 \\
\end{array}$ & $\begin{array}{l}\text { Yes } \\
\text { Yes } \\
\text { Yes } \\
486 \\
0.335\end{array}$ & $\begin{array}{l}\text { Yes } \\
\text { Yes } \\
\text { Yes } \\
486 \\
0.422 \\
\end{array}$ & \\
\hline \multicolumn{5}{|l|}{ Panel C: Social Performance } \\
\hline \multirow[t]{2}{*}{ Dependent Variables } & $\begin{array}{c}\text { Ln(Number of } \\
\text { Active Borrowers) }\end{array}$ & Average Loan Size & $\begin{array}{c}\text { Ln(Number of } \\
\text { Active Borrowers) }\end{array}$ & Average Loan Size \\
\hline & $(1)$ & $(2)$ & (3) & (4) \\
\hline Dummy_Islamic MFI & $\begin{array}{l}0.191 * * * \\
(3.25)\end{array}$ & $\begin{array}{c}-0.368 * * * \\
(-3.57)\end{array}$ & $\begin{array}{l}0.187 * * * \\
(3.14)\end{array}$ & $\begin{array}{c}-0.064 * * * \\
(-3.25)\end{array}$ \\
\hline Dummy_Islamic MFIs*ROA & & & $\begin{array}{c}0.428 * * * \\
(3.85)\end{array}$ & $\begin{array}{c}-0.076^{* * *} \\
(-2.84)\end{array}$ \\
\hline ROA & & & $\begin{array}{c}-0.637^{* *} \\
(-2.25)\end{array}$ & $\begin{array}{c}0.547 * * \\
(2.18)\end{array}$ \\
\hline Controls & Yes & Yes & Yes & Yes \\
\hline Country Fixed Effects & Yes & Yes & Yes & Yes \\
\hline Year Fixed Effects & Yes & Yes & Yes & Yes \\
\hline $\mathrm{N}$ & 486 & 486 & 486 & 486 \\
\hline adj. $R^{2}$ & 0.642 & 0.583 & 0.565 & 0.375 \\
\hline
\end{tabular}


Appendix A

Definitions of Variables

\begin{tabular}{|c|c|}
\hline Variable Name & Definition \\
\hline \multicolumn{2}{|l|}{ Dependent Variables } \\
\hline Operational Costs & $\begin{array}{l}\text { The operational costs divided by the gross loan portfolio, which mainly covers wages and } \\
\text { administrative costs }\end{array}$ \\
\hline Administrative Costs & The total administrative costs on the loan portfolio divided by the total assets \\
\hline Return on Assets (ROA) & The ratio of net operating income to total assets \\
\hline Operating Self-Sufficiency (OSS) & $\begin{array}{l}\text { Total financial revenue divided by the sum of financial expense, operating expense and } \\
\text { loan loss provision expense }\end{array}$ \\
\hline PaR $>90$ days & The percentage of the portfolio that is overdue for more than 90 days \\
\hline Write-off Ratio & $\begin{array}{l}\text { The percentage of the total amount of loans written off to gross loan portfolio Write off is } \\
\text { an accounting procedure that removes the outstanding balance of loans from the items of } \\
\text { Gross Loan Portfolio and Impairment Loss Allowance when these loans are recognised as } \\
\text { uncollectable }\end{array}$ \\
\hline Loan Loss Rate & The ratio of the difference between write-offs and loans recovered to gross loan portfolio \\
\hline Number of Active Borrowers & The natural logarithm of the total number of individuals that an MFI serves \\
\hline Average Loan Size & The average loan size per borrower divided by country group national income per capita \\
\hline \multicolumn{2}{|l|}{ Explanatory Variable } \\
\hline Islamic MFI & A dummy variable equal to one if an MFI is Islamic, and 0 if it is conventional \\
\hline \multicolumn{2}{|l|}{ Control Variables } \\
\hline Total Assets & The natural logarithm of total assets \\
\hline Leverage & The ratio of total debt over total equity \\
\hline Total Assets Growth & $\begin{array}{l}\text { The ratio of the difference of current year total assets and the previous year total assets } \\
\text { divided by the previous year total assets. }\end{array}$ \\
\hline Portfolio Yield & $\begin{array}{l}\text { The interest revenue divided by gross loan portfolio for conventional MFIs; the mark-up } \\
\text { and dividend divided by gross loan portfolio for Islamic MFIs. Mark-up is the fixed income } \\
\text { of Marabaha (Islamic microfinance product). }\end{array}$ \\
\hline Deposits-to-Assets & The ratio of total deposits divided by total assets \\
\hline Age Mature & A dummy variable equal to one if an MFI is mature \\
\hline Age_New & A dummy variable equal to one if an MFI is new \\
\hline Target Market_Low End & A dummy variable equal to one if an MFI targets low-end markets \\
\hline Target Market_High End & A dummy variable equal to one if an MFI targets high-end markets \\
\hline Target Market_Small Business & A dummy variable equal to one if an MFI targets small business markets \\
\hline For Regulated & A dummy variable equal to one if an MFI is regulated; zero if it is not regulated \\
\hline For Profit & A dummy variable equal to one if an MFI is profit-oriented \\
\hline Disclosure Ratings & $\begin{array}{l}\text { Disclosure quality ratings by the MIX Market database. One indicates the lowes } \\
\text { disclosure quality and five indicates the highest disclosure quality }\end{array}$ \\
\hline Number of Offices & Total number of offices \\
\hline
\end{tabular}


Appendix B

Regulatory support for Islamic MFIs

\begin{tabular}{|c|c|}
\hline Country & Regulation \\
\hline Afghanistan & $\begin{array}{l}\text { In 2015, Afghanistan's new banking law formalizes basic regulations that govern (micro)banks' ability to offer } \\
\text { Sharia-compliant services (Russel, 2016). }\end{array}$ \\
\hline Bangladesh & $\begin{array}{l}\text { The Bangladesh government signs the Charter of Islamic Development Bank in 1974, in which it commits itself } \\
\text { to reorganize its financial system as per Islamic Sharia. Under the government poverty-alleviation promotion, } \\
\text { Islamic Bank Bangladesh Limited launches the Rural Development Scheme" by adopting Islamic microfinance } \\
\text { products through a community development approach (Jahan, 2012). }\end{array}$ \\
\hline Egypt & $\begin{array}{l}\text { In } 2010 \text {, the Muslim Brotherhood government, along with the Egyptian Islamic Finance Association, makes } \\
\text { Islamic finance and microfinance as one central part of its economic policy aiming at turning } 35 \% \text { of the total } \\
\text { financial market into Islamic by } 2017 \text { (Girona, Aghina, and Boundaoui, 2014). }\end{array}$ \\
\hline Indonesia & $\begin{array}{l}\text { In 1994, the Indonesia government places microfinance (both conventional and Islamic) as a vital component in } \\
\text { its poverty alleviation strategies and programmes. Following the government's Islamic Banking Act of 2008, } \\
\text { Bank Indonesia (the central bank) launches the dual (micro)finance system: conventional and Islamic ones } \\
\text { (Kustin, 2015). }\end{array}$ \\
\hline Pakistan & $\begin{array}{l}\text { In the early } 2000 \text { s, the State Bank of Pakistan (the central bank) has formulated guidelines for provisions of } \\
\text { Islamic microfinance produces and services. These guidelines aim to enhance the scope of microfinance services } \\
\text { and products consistent with Sharia principles, and to specify the four types of institutions eligible in providing } \\
\text { Islamic microfinance (Kustin, 2015). }\end{array}$ \\
\hline Sudan & $\begin{array}{l}\text { In the early } 2000 \mathrm{~s} \text {, the Sudan government transforms the existing dual economic system into Islamic financial } \\
\text { system. This reform has enahnced Islamic financial infrastructures and provided a favorable environment for } \\
\text { Islamic microfinance. In 2006, Central Bank of Sudan takes the initiative of formulating a vision for developing } \\
\text { and expanding microfinance sector in Sudan (Ahmed and Ammar, 2015). }\end{array}$ \\
\hline Yemen & $\begin{array}{l}\text { In 1997, the Yemen government and the United Nations establishes the Hodeidah Microfinance Program, which } \\
\text { aims to apply the Islamic financial principles to the microfinance sector (Ahmed and Grace, 2001). }\end{array}$ \\
\hline
\end{tabular}

Appendix C

The Distribution of Conventional and Islamic MFIs in Each Country

\begin{tabular}{|c|c|c|c|}
\hline Country & Number of conventional MFIs & Number of Islamic MFIs & Percentage of Islamic MFIs \\
\hline Afghanistan & 15 & 3 & $16.67 \%$ \\
\hline Bangladesh & 79 & 2 & $2.47 \%$ \\
\hline Indonesia & 69 & 5 & $6.76 \%$ \\
\hline Iraq & 8 & 4 & $30.33 \%$ \\
\hline Jordan & 6 & 2 & $25.00 \%$ \\
\hline Kosovo & 11 & 1 & $8.33 \%$ \\
\hline Kyrgyzstan & 45 & 1 & $2.17 \%$ \\
\hline Lebanon & 5 & 1 & $16.67 \%$ \\
\hline Pakistan & 31 & 5 & $13.89 \%$ \\
\hline Palestine & 5 & 6 & $54.55 \%$ \\
\hline Syria & 2 & 1 & $33.33 \%$ \\
\hline Yemen & 5 & 4 & $44.44 \%$ \\
\hline
\end{tabular}


Appendix D

MFI Name and Location

\begin{tabular}{|c|c|}
\hline MFI Name & Location \\
\hline Asasah & Pakistan \\
\hline TMSS & Bangladesh \\
\hline Akhuwat & Pakistan \\
\hline FINCA - AFG & Afghanistan \\
\hline Al Majmoua & Lebanon \\
\hline Azal & Yemen \\
\hline Bank of Khyber & Pakistan \\
\hline Kompanion & Kyrgyzstan \\
\hline FATEN & Palestine \\
\hline DEF & Jordan \\
\hline MBK Ventura & Indonesia \\
\hline $\mathrm{ACAD}$ & Palestine \\
\hline ASALA & Palestine \\
\hline Jabal Al Hoss & Syria \\
\hline PASED & Sudan \\
\hline START & Kosovo \\
\hline PARC & Palestine \\
\hline Tadhamon & Yemen \\
\hline Al-Thiqa & Iraq \\
\hline BMT Pringsewu & Indonesia \\
\hline Abyan & Yemen \\
\hline FINCA - JOR & Jordan \\
\hline Reef & Palestine \\
\hline BMT Pelita Insa & Indonesia \\
\hline BMT Kayu Manis & Indonesia \\
\hline CHF Iraq & Iraq \\
\hline CWCD & Pakistan \\
\hline Al Aman & Iraq \\
\hline Al Amal Bank & Yemen \\
\hline Farz Foundation & Pakistan \\
\hline Al Takadum & Iraq \\
\hline BMT Sanama & Indonesia \\
\hline Mutahid & Afghanistan \\
\hline Muslim Aid & Bangladesh \\
\hline Islamic Relief & Palestine \\
\hline IIFC Group & Afghanistan \\
\hline
\end{tabular}

